\title{
A comparison of immunoblot and DNA restriction patterns in characterising methicillin-resistant isolates of Staphylococcus aureus
}

\author{
J.P. BURNIE, RUTH C. MATTHEWS, WOEI LEE and D. MURDOCH \\ Department of Medical Microbiology, St Bartholomew's Hospital, West Smithfield, London EC1A 7BE
}

\begin{abstract}
Summary. The ability of $E c o$ Rl restriction enzyme fragmentation patterns and of immunoblotting to differentiate methicillin-resistant isolates of Staphylococcus aureus were compared. All isolates examined were typable by both methods and the reproducibility of each was excellent. Immunoblotting differentiated eight types and DNA restriction patterns four. The former technique was of value in characterising methicillin-resistant isolates of $S$. aureus and controlling an outbreak due to them.
\end{abstract}

\section{Introduction}

In the UK, especially in the South East of England, there is an epidemic of infection caused by a methicillin-resistant strain of Staphylococcus aureus (EMRSA), the severity of which has led to the formulation of methods to control it (Report, 1986). Their implementation is expensive; therefore, it is important to identify isolates of EMRSA rapidly and accurately.

Identification of EMRSA is based on the strain's antibiogram and phage-typing characteristics. The epidemic strain is always resistant to benzylpenicillin, methicillin, erythromycin and tetracycline and susceptible to vancomycin, and $70 \%$ of isolates are resistant to gentamicin, but resistance to fusidic acid or rifampicin is rare. Its phage-typing pattern varies although most isolates type weakly with phage 85 (Marples et al., 1986).

The lack of discrimination provided by antibiograms or phage typing encouraged Lee and Burnie (1988) to develop an immunoblot method to identify these isolates and distinguish them from other methicillin-resistant strains. Immunoblot fingerprinting is a phenotype-based system that depends on the patterns seen when staphylococcal antigens produced by lysostaphin degradation react, after electrophoresis, with hyperimmune rabbit antiserum. This technique was subsequently evaluated by staff of the Division of Hospital Infection in the Central Public Health Laboratory, Colindale, where its discriminatory superiority over antibiograms and phage typing was confirmed (Gaston et al., 1988). Krikler et al. (1986) developed a parallel method for characterising methicillin-sensitive iso-

Received 1 Aug. 1988; accepted 1 Feb. 1989. lates; in their method culture supernates were tested against normal human serum. Stephenson et al. (1986) described strain characterisation based on autoradiographs; this identified an outbreak due to EMRSA.

Immunoblotting has two disadvantages: its reproducibility is linked to a standardised antibody probe (Burnie and Matthews, 1987) and it recognises phenotypic rather than genotypic characters. Restriction endonuclease digest pattern analysis has been developed to characterise isolates of many pathogens including Candida albicans (Scherer and Stevens, 1987), Vibrio cholerae (Feng-Yin et al., 1986), Campylobacter pylori (Langenberg et al., 1986), and coagulase-negative staphylococci (Burnie and Lee, 1988), and because the pattern of the fragments is governed by the DNA sequence of the host genome it is not affected by phenotypic variation.

This paper describes DNA restriction pattern analysis of type isolates earlier defined by immunoblotting (Lee and Burnie, 1988) and a comparison of both typing methods in characterising isolates from an outbreak caused by a non-epidemic methicillin-resistant strain of Staphylococcus aureus in an oncology unit.

\section{Material and methods}

\section{Isolates}

Twenty-six strains representing seven of the eight types defined by immunoblotting (Lee and Burnie, 1988) and 14 isolates from the outbreak were examined. Immunoblot types 1,3 and 8 were each represented by a single isolate; immunoblot type 2 (EMRSA) by 13 isolates; 
immunoblot type 4 by three isolates; immunoblot type 6 by five isolates; and immunoblot type 7 by two isolates. All isolates were coagulase positive by both slide and tube tests. They were stored on nutrient-agar slopes at room temperature. During the outbreak, growth from screening swabs was enriched by culture in broth containing colistin $10 \mathrm{mg} / \mathrm{L}$ and nalidixic acid $5 \mathrm{mg} / \mathrm{L}$ and subculture on to nutrient agar containing methicillin $4 \mathrm{mg} / \mathrm{L}$.

\section{$D N A$ restriction pattern analysis}

Preparation of DNA. The procedure was modified from that of Burnie and Lee (1988). Cocci grown overnight at $37^{\circ} \mathrm{C}$ in $5 \mathrm{ml}$ of Tryptone Soya Broth (Oxoid) were collected by centrifugation and washed in $1 \mathrm{ml}$ of a solution consisting of $10 \mathrm{~mm}$ Tris hydroxymethylaminomethane $(\mathrm{pH} 8)$ and $1 \mathrm{mM}$ ethylenediamene tetraacetic acid (EDTA, pH 8) (TE). Fresh TE, $0.5 \mathrm{ml}$, containing $100 \mu \mathrm{l}$ of lysostaphin (Sigma) at a concentration of $1 \mathrm{mg} /$ $\mathrm{ml}$, was added to each cell pellet and the mixture was incubated at $37^{\circ} \mathrm{C}$ in a waterbath for $1 \mathrm{~h}$. Subsequently, $0.5 \mathrm{ml}$ of a solution containing $0.05 \mathrm{M}$ EDTA ( $\mathrm{pH} 8.5$ ) and sodium dodecylsulphate $3 \mathrm{mg} / \mathrm{ml}$ was added, followed by $30 \mu \mathrm{l}$ of diethylpyrocarbonate (Sigma). This mixture was incubated in a waterbath at $68^{\circ} \mathrm{C}$ for $30 \mathrm{~min}$ before $50 \mu \mathrm{l}$ of $5 \mathrm{M}$ potassium acetate was added; the mixture was centrifuged and the supernate was pipetted into $1 \mathrm{ml}$ of cold absolute ethanol. This was mixed, left at $-20^{\circ} \mathrm{C}$ for $30 \mathrm{~min}$, then clarified by centrifugation for 5 $\min$. The supernate was discarded. The precipitate was washed with $1 \mathrm{ml}$ of cold $70 \%$ ethanol, the ethanol was removed, and the precipitate was vacuum-dried for 10 min in a speed vacuum concentrator (Genetech Research Industries, Bishop Stortford). When dry, the precipitate was redissolved in $0.1 \mathrm{ml}$ of TE, $\mathrm{pH} 8$, to which was added $12 \mu$ l of a solution in TE of RNAase (ribonucleaseA from bovine pancreas, types 1-AS, Sigma) $10 \mathrm{mg} / \mathrm{ml}$, which had been boiled for $10 \mathrm{~min}$. The suspension was incubated at $37^{\circ} \mathrm{C}$ for $30 \mathrm{~min}$. One tenth volume $(10 \mu \mathrm{l})$ of $3 \mathrm{M}$ sodium acetate (pH 5.5) and 2 volumes $(200 \mu \mathrm{l})$ of cold absolute ethanol were added and the mixture was kept at $-20^{\circ} \mathrm{C}$ overnight. It was then centrifuged; the precipitate was washed with $70 \%$ cold ethanol, vacuum dried and resuspended in $90 \mu \mathrm{l}$ of TE, $\mathrm{pH} 8$, by incubating at $55^{\circ} \mathrm{C}$ for $30-60$ mins. This was then stored at $-20^{\circ} \mathrm{C}$.

Restriction endonuclease digestion of DNA. EcoR 1 reaction buffer (a tenfold concentrate), $10 \mu \mathrm{l}$, and 40 units $(4 \mu \mathrm{l})$ of EcoRl enzyme (NBL Enzymes Division, Cramlington, UK) were added to $90 \mu \mathrm{l}$ of DNA suspended in TE. Endonuclease digestion was carried out to completion by incubation at $37^{\circ} \mathrm{C}$ for $2 \mathrm{~h}$. Digestion was stopped by heating to $70^{\circ} \mathrm{C}$ for $10 \mathrm{~min}$. A $30 \mu \mathrm{l}$ sample of HindIII digested lambda DNA $(150 \mu \mathrm{g} / \mathrm{ml})$ was used as a DNA marker. As markers, $30 \mu \mathrm{l}$ of Bromophenol blue buffer, consisting of $40 \mathrm{mg}$ of agarose dissolved in $20 \mathrm{ml}$ of $10 \mathrm{mM}$ Tris, $\mathrm{pH} 7 \cdot 5,20 \mathrm{mM}$ EDTA, glycerol $10 \%$ and bromophenol blue $0.01 \%$, was added to the digested DNA samples.

Gel electrophoresis and photography. The DNA frag- ments were separated by constant voltage electrophoresis $(40 \mathrm{~V})$ overnight in a horizontal gel containing agarose $0.8 \%$ with a Tris-borate EDTA buffer system. They were visualised under UV light and photographed with Polaroid film type 57.

\section{Immunoblotting}

Preparation of lysostaphin degraded extract. Staphylococci grown overnight in $2 \mathrm{ml}$ of Tryptone Soya Broth at $37^{\circ} \mathrm{C}$ were collected by centrifugation at $3000 \mathrm{~g}$ for $10 \mathrm{~min}$, resuspended in $100 \mu \mathrm{l}$ of sterile distilled water mixed with $100 \mu \mathrm{l}$ of a solution of lysostaphin (Sigma) at a concentration of $200 \mu \mathrm{g} / \mathrm{ml}$, and incubated for $30 \mathrm{~min}$ on a shaker at $37^{\circ} \mathrm{C}$. After centrifugation, $60 \mu \mathrm{l}$ of the supernate was solubilised in $60 \mu \mathrm{l}$ of a solution containing sodium dodecyl sulphate $2.6 \%$ and mercaptoethanol $1.3 \%$. This was heated at $100^{\circ} \mathrm{C}$ for $5 \mathrm{~min}$.

Preparation of antisera. Cells of outbreak isolate No. 1, grown overnight at $37^{\circ} \mathrm{C}$ on Blood Agar (Oxoid) were harvested, centrifuged at $3000 \mathrm{~g}$ for $10 \mathrm{~min}$ and washed three times in distilled water. The washed cells were frozen at $-20^{\circ} \mathrm{C}$ in an Xpress (LKB, Bromma, Sweden). They were then crushed twice at $12 \mathrm{~m}$ Pascals. The extracts were thawed and centrifuged at $12000 \mathrm{~g}$ for 10 $\mathrm{min}$. This produced a supernate with a protein concentration of approximately $100 \mathrm{mg} / \mathrm{ml}$. Two New Zealand White rabbits were each inoculated subcutaneously with $25 \mathrm{mg}$ of the supernate mixed with $1 \mathrm{ml}$ of sterile water and $1 \mathrm{ml}$ of complete Freund's adjuvant. They were inoculated again after 14 days and bled after a further 14 days. The antisera were pooled for subsequent experiments. .

Gel electrophoresis. The lysostaphin-degraded staphylococcal extract, $75 \mu \mathrm{l}$, prepared as above, was loaded into each well of a polyacrylamide $10 \%$ gel. Electrophoresis was performed for $4 \mathrm{~h}$ (in a discontinuous buffer system) until the tracking dye was within $1 \mathrm{~cm}$ of the bottom of the gel (Laemmli, 1970). Standards of myosin (mol. wt 200000 ); $\beta$-galactosidase (mol. wt 116250 ); phosphorylase B (mol. wt 92500 ); bovine serum albumin (mol. wt 66 200); ovalbumin (mol. wt 45000 ); carbonic anhydrase (mol. wt 31000 ); soya bean trypsin inhibitor (mol. wt 21500 ) and lysozyme (mol. wt 14400 ) were included.

Immunoblot transfer and strain. Proteins were transferred to nitrocellulose paper (BioRad laboratories, Richmond, CA, USA) in $25 \mathrm{~mm}$ Tris, $192 \mathrm{~mm}$ glycine buffer, $\mathrm{pH} 8 \cdot 3$, containing methanol $20 \%$ at $25^{\circ} \mathrm{C}$ with a current of $0.5 \mathrm{~A}$ applied for $45 \mathrm{~min}$ in an LKB transblot cell. Protein sites were saturated by incubating in bovine serum albumin (Sigma) 3\% in buffered saline ( $\mathrm{NaCl} \mathrm{0.9 \%}$ and $10 \mathrm{~mm}$ Tris, $\mathrm{pH} \mathrm{7.4)}$ at $4^{\circ} \mathrm{C}$ overnight. The nitrocellulose membrane was then incubated at $25^{\circ} \mathrm{C}$ for $2 \mathrm{~h}$ with rabbit antiserum diluted 1 in 20 in bovine serum albumin $3 \%$ and Tween $200.05 \%$. After washing five times in saline $0.9 \%$ and Tween $200.05 \%$, the nitrocellulose paper was incubated for $1 \mathrm{~h}$ at $25^{\circ} \mathrm{C}$ with alkaline phosphataseconjugated goat anti-rabbit IgG (Sigma) diluted 1 in 1000 in bovine serum albumin 3\%. After washing again in saline $0.9 \%$ and Tween $200.05 \%$, the membrane was 
incubated for $5-15 \mathrm{~min}$ at $25^{\circ} \mathrm{C}$ with $10 \mathrm{ml}$ of buffer (100 mM Tris hydrochloride, $\mathrm{pH} 9.5,100 \mathrm{mM} \mathrm{NaCl}, 5 \mathrm{mM}$ $\mathrm{MgCl}_{2}$ ) containing a mixture of $660 \mu \mathrm{l}$ of a solution of nitroblue tetrazolium (NBT) consisting of NBT $50 \mathrm{mg} /$ $\mathrm{ml}$ in $\mathrm{B}, \mathrm{N}$-dimethylformamide $70 \%$ and $330 \mu \mathrm{l}$ of a solution of 5'bromo'4'chloro' 3 indolylphosphate $50 \mathrm{mg} /$ $\mathrm{ml}$ in $70 \% \mathrm{~N}, \mathrm{~N}$-dimethylformamide. The reaction was stopped by washing in water.

\section{Antibiotic susceptibility}

Antibiotic sensitivity was tested by the method of Stokes and Waterworth (1972) on Isosensitest Agar (Oxoid, CM471) with disks containing $10 \mu \mathrm{g}$ of each of methicillin, tetracycline, gentamicin, erythromycin, neomycin, fusidic acid and chloramphenicol, $2 \mu \mathrm{g}$ of rifampicin and clindamycin and $1 \mu \mathrm{g}$ of benzylpenicillin. All tests were incubated at $35^{\circ} \mathrm{C}$ except for that with methicillin which was incubated at $30^{\circ} \mathrm{C}$.

\section{Phage typing}

This was performed by staff of the Division of Hospital Infection, Central Public Health Laboratory, Colindale by the standard method (Parker, 1972).

\section{The outbreak}

On 13 Aug. 1987, a patient (Case 1) with a diagnosis of mycosis fungoides was admitted from Italy to the open ward of the male Oncology Unit, St Bartholomew's Hospital. On 14 Aug. a lesion on his neck was swabbed. On 18 Aug. his condition had so deteriorated that he was transferred to the Intensive Care Unit. By 20 Aug. a methicillin-resistant strain of $S$. aureus had been isolated from the neck swab. The same organism was subsequently isolated from his nose, axilla, mouth, hair, groin, perineum, and a scalp wound. The patient was transferred on 22 Aug. to a side room in the female Oncology Unit where he remained until his death on 30 Aug.

On 18 Aug. a second patient (Case 2), transferred from a hospital in Essex, was found to be colonised by a strain of methicillin-resistant $S$. aureus. On 20 Aug. a third patient (Case 3) transferred from Whipps Cross Hospital was also found to be colonised by a methicillin-resistant strain of $S$. aureus. On 21 Aug. skin lesions and the nose and perineum of all patients in the male oncology ward were swabbed. As a result, three further patients (Cases 4-6) were found to be carriers of a methicillin-resistant $S$. aureus. Thereafter all patients bathed daily with Betadine $^{\circledR}$ and were treated with Naseptin ${ }^{\circledR}$ cream intranasally.

On 25 Aug. nasal and perineal swabs were taken from the staff on the Oncology Unit; three doctors (Cases 7, 8 and 9) colonised by methicillin-resistant $S$. aureus were identified as a result. On 1 Sep. they began treatment with intra-nasal mupirocin cream and daily Betadine washes. On 28 Aug. two further patients with leukaemia (Cases 10 and 11) were found to be carriers of methicillin- resistant $S$. aureus, the organisms being grown from throat swabs taken as part of an antibiotic trial. In Case 11 the site of an intravenous Hickman catheter subsequently became infected; the catheter was removed on 3 Sep.

On 1 Sep. swabs were taken from the nose and perineum of all patients and staff in both Oncology Wards. MRSA were not isolated from any of the patients but two nurses (Cases 12 and 13) from the female ward were found to be nasal carriers. Both had cared for the index case (Case 1). On 14 Sep. a further patient (Case 14) in the male Oncology Ward was found to be colonised. As a result, nasal and perineal swabs were again taken from staff and patients in this ward; MRSA were not isolated, nor were MRSA isolated subsequently.

\section{Results}

\section{Comparison of DNA restriction patterns and immunoblot types}

DNA restriction enzyme digests contained five bands of $8 \cdot 8-9.4 \mathrm{~kb}, 5 \cdot 3-6.2 \mathrm{~kb}, 4 \cdot 2 \mathrm{~kb}, 4 \mathrm{~kb}$ and $3.4 \mathrm{~kb}$ (table I), the patterns of which were sufficiently reproducible to serve as a basis for characterising individual strains. Differences of a single restriction fragment have been accepted as characterising distinct strains (Burnie and Lee, 1988) compared with differences of at least three antigenic bands before strains can be distinguished by immunoblotting. The DNA restriction fragment patterns of single isolates of each immunoblot type are shown in fig. 1. All the isolates were typable by DNA analysis and their restriction patterns were reproducible, as judged by at least two separate examinations. However, strain discrimination was poorer than with immunoblotting in that immunoblot types 1, 2 and 3 were all of DNA type 1 (table II). Immunoblot type 2 was an EMRSA and immunoblot types 1 and 3 were minor variants of

Table I. Details of the DNA types

\begin{tabular}{lcccc}
\hline & \multicolumn{5}{c}{ DNA type } \\
\cline { 2 - 5 } $\begin{array}{c}\text { Band } \\
(\mathrm{kb})\end{array}$ & 1 & 2 & 3 & 4 \\
\hline $8 \cdot 8-9 \cdot 4$ & + & DB & DB & + \\
$5 \cdot 3-6 \cdot 2$ & TB & DB & TB & DB \\
$4 \cdot 2$ & + & + & $+^{\mathrm{a}}$ & $+^{\mathrm{a}}$ \\
$4 \cdot 0$ & + & + & - & - \\
$3 \cdot 4$ & + & + & DB & DB
\end{tabular}

$+=$ Band present; $-=$ band absent; TB $=$ triple band; $\mathrm{DB}=$ double band $;+^{\mathrm{a}}=$ band consistently low . 


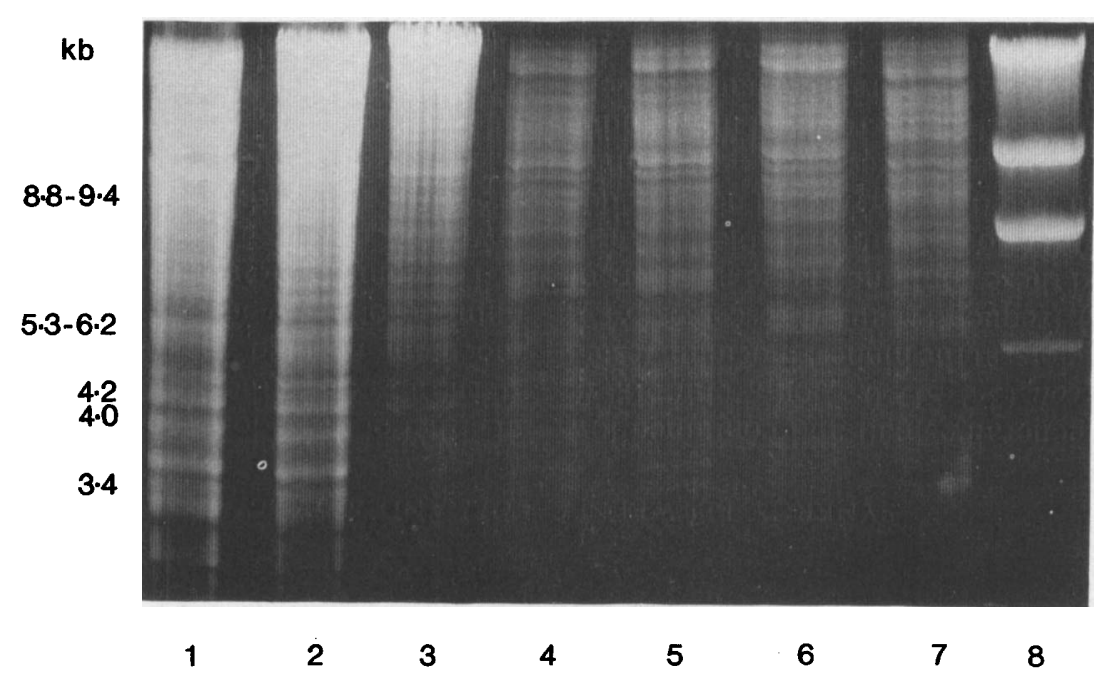

Fig. 1. DNA restriction patterns. Tracks 1-3, DNA type 1 ; tracks 4 and 5, DNA type 2; track 6, DNA type 3; track 7, DNA type $4 ;$ track 8 , mol. wt markers $(21 \cdot 0,9 \cdot 4,6 \cdot 6$ and $4 \cdot 4 \mathrm{~kb})$.

it; type 1 was rifampicin resistant and type 3 typed with an extra phage (phage 83a).

The DNA restriction pattern of immunoblot type 4 was completely distinct. These isolates all came from Pinderfields Hospital where they are reported as being of lower virulence than EMRSA. They typed with phages 47, 54 and 75 (Lacey et al., 1986).

Immunoblot types 6 and 7 had identical DNA restriction fragment patterns. Immunoblot type 6 typed with phages 47 and 54 at RTD whereas isolates of immunoblot type 7 were non-typable. Type- 6 isolates were sensitive to gentamicin and rifampicin but resistant to chloramphenicol whereas type-7 isolates were sensitive to chloram-

Table II. Comparison of the immunoblot and DNA types

\begin{tabular}{|c|c|c|c|}
\hline $\begin{array}{l}\text { Number } \\
\text { of isolates } \\
\text { examined }\end{array}$ & $\begin{array}{l}\text { Immunoblot } \\
\text { type }\end{array}$ & $\begin{array}{c}\text { DNA } \\
\text { type }\end{array}$ & Comments \\
\hline 1 & 1 & 1 & $\begin{array}{l}\text { Rifampicin resistant variant of } \\
\text { EMRSA }\end{array}$ \\
\hline 13 & 2 & 1 & EMRSA \\
\hline 1 & 3 & 1 & $\begin{array}{l}\text { Indistinguishable from } \\
\text { EMRSA except typed with } \\
\text { phage } 83 \mathrm{~A}\end{array}$ \\
\hline 3 & 4 & 3 & All from Pinderfields Hospital \\
\hline 5 & 6 & 2 & $\begin{array}{l}\text { All from Hull Royal Infirmary, } \\
\text { St James' Hospital or St Luke's } \\
\text { Hospital, Bradford }\end{array}$ \\
\hline 2 & 7 & 2 & All from Hull Royal Infirmary \\
\hline 1 & 8 & 4 & $\begin{array}{l}\text { Resistant to all antibiotics } \\
\text { tested except vancomycin. } \\
\text { From Egypt }\end{array}$ \\
\hline
\end{tabular}

phenicol but resistant to gentamicin and rifampicin (Lee and Burnie, 1988). All of the isolates of immunoblot types 6 and 7 came from hospitals in the North of England and both types were found at the same time at Hull Royal Infirmary. Immunoblot type 8 was an isolate from a patient from Egypt, unique in that it was not phage-typable, was resistant to all the antibiotics tested except vancomycin, and had distinct DNA restriction fragment and immunoblot patterns.

\section{DNA restriction pattern and immunoblot characterisation of outbreak strains}

In all, 14 isolates of methicillin-resistant $S$. aureus were obtained from 118 screening specimens taken from 73 patients and 87 screening specimens taken from staff during the outbreak.

Details of the DNA restriction patterns, immunoblot types and phage types of these isolates are given in table III. Two types were distinguished by immunoblotting: isolates from cases 2 and 5 were typical EMRSA (illustrated in fig. 2 by tracks 1 and 4) whereas the second type was a new immunoblot type (type 9) isolated from cases 1, 3, 4 and 6-14. Six of these isolates are illustrated in fig. 2. The EMRSA isolates had bands of $160,132,116,92,75$, $61,54,53,52,50$ and $38 \mathrm{Kda}$. The immunoblot type- 9 isolates had bands of $160,145,116,92,75$, $55,54,50$ and $38 \mathrm{Kda}$. The brightest band for this strain was at $54 \mathrm{Kda}$ compared with $52 \mathrm{Kda}$ for the epidemic methicillin-resistant strain.

Fig. 3 illustrates the DNA restriction patterns of four EMRSA strains and of the isolate from Case 1 


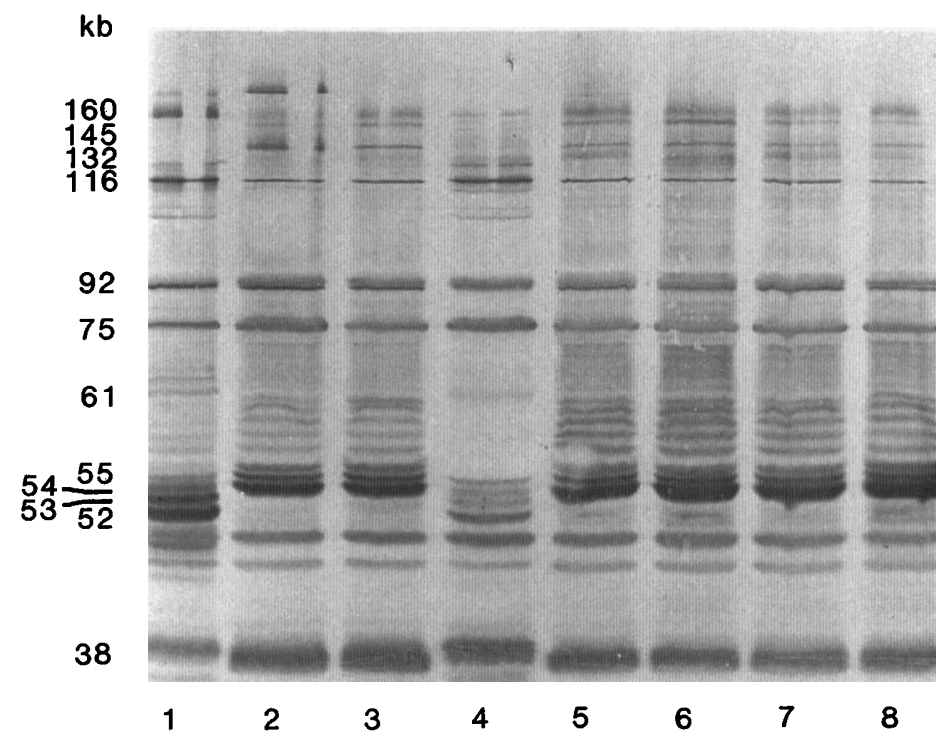

Fig. 2. Immunoblot patterns. Track 1, Case 2; track 2, Case 1; track 3, Case 3; track 4, Case 5; track 6, Case 6; track 7, Case 8; track 8, Case 9.

(track 5). They are indistinguishable. However their phage types differed, in that the epidemic strain reacted with phage 85 whereas the new strain was always susceptible to phage 84 and occasionally susceptible to phage 75 . The strains' antibiograms were similar: both were resistant to benzylpenicillin, erythromycin, clindamycin, tetracycline, gentamicin and flucloxacillin and sensitive to chloramphenicol, fucidin, rifampicin and vancomycin. There was a small difference in sensitivity testing: benzylpenicillin always produced a small

Table III. Details of the immunoblot, DNA and phage types of the outbreak isolates

\begin{tabular}{|c|c|c|c|c|}
\hline \multirow[b]{2}{*}{ Case no. } & \multirow{2}{*}{$\underset{\text { type }}{\text { Immunoblot }}$} & \multirow{2}{*}{$\begin{array}{c}\text { DNA } \\
\text { type }\end{array}$} & \multicolumn{2}{|c|}{ Phage type } \\
\hline & & & RTD & $\mathrm{RTD} \times 100$ \\
\hline 1 & 9 & 1 & 84 & 84 \\
\hline 2 & 2 & 1 & NT & 85 \\
\hline 3 & 9 & 1 & 84 & 84 \\
\hline 4 & 9 & 1 & 84 & 84 \\
\hline 5 & 2 & 1 & NT & 85 \\
\hline 6 & 9 & $i$ & NT & 75,84 \\
\hline 7 & 9 & 1 & 84 & 75,84 \\
\hline 8 & 9 & 1 & NT & 84 \\
\hline 9 & 9 & 1 & NT & 84 \\
\hline 10 & 9 & 1 & NT & 84 \\
\hline 11 & 9 & 1 & NT & 84 \\
\hline 12 & 9 & 1 & NT & 84 \\
\hline 13 & 9 & 1 & NT & 84 \\
\hline 14 & 9 & 1 & 84 & 84 \\
\hline
\end{tabular}

RTD $=$ Routine test dose $;$ NT $=$ non-typable.
( $5 \mathrm{~mm}$ ) zone of inhibition with the strain from Case 1 but never with the epidemic strain.

Thus, the isolate from Case 1 was identical with the EMRSA as judged by DNA restriction pattern analysis but was considerably different phenotypically as measured by immunoblot type, variation in benzylpenicillin sensitivity, and different susceptibility to phages.

\section{Discussion}

When DNA restriction pattern analysis was applied to methicillin-resistant isolates of $S$. aureus

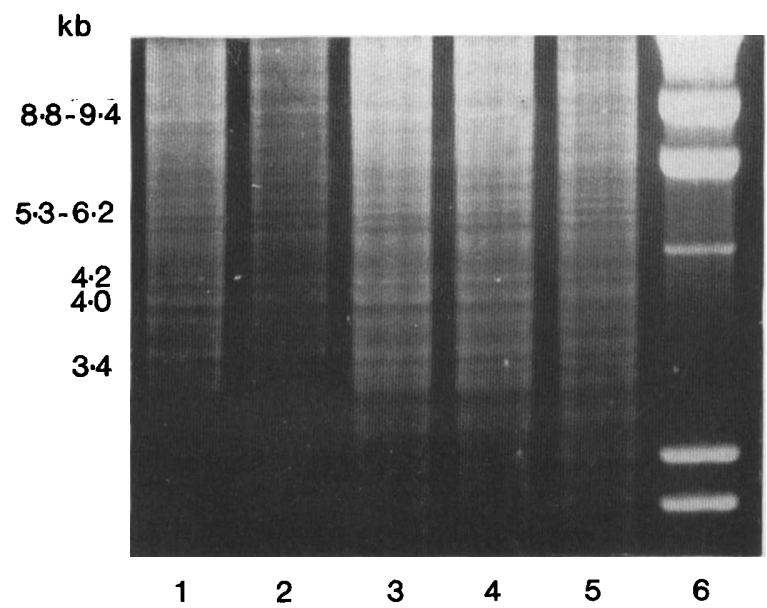

Fig. 3. DNA restriction patterns. Tracks $1-4$, DNA type 1 (epidemic strains); track 5, DNA type 1, immunoblot type 9 (outbreak strain); track 6 mol. wt markers $(9 \cdot 4,6 \cdot 6,4 \cdot 4,2 \cdot 3$ and $2 \cdot 0 \mathrm{~kb})$. 
previously characterised by immunoblot typing (Lee and Burnie, 1988), all isolates were typable by the former method, and the five-band fragment pattern, on which the analysis was based, was reproducible. Discrimination however was poorer, in that the eight original immunoblot types corresponded to four DNA types only.

DNA type 2 represented several small clusters of cases in Northern England, in which, although not large, several patients in each of the hospitals involved were infected. Immunoblot typing demonstrated two separate clusters in Hull Royal Infirmary, a finding confirmed by differences in the strains' phage types and antibiograms. DNA typing suggests that the strains causing these two clusters were phenotypic variants of a single strain because they were genotypically similar. Both outbreaks were self limiting; the precautions normally taken to limit the spread of EMRSA were not instigated.

DNA type 3 represented isolates from Pinderfields Hospital. Both their DNA restriction and immunoblot patterns were unique. These isolates are clearly a different strain of methicillin-resistant $S$. aureus than the EMRSA, so that it is not surprising that they are of lower virulence (Lacey et al., 1986). DNA type 4 was isolated from one patient only and was not typable by phages; it was sensitive to vancomycin only and had a unique immunoblot pattern.

Immunoblot typing, which is phenotype based, was more discriminatory than DNA (genotypebased) typing. This may be due partly to the use of a single restriction enzyme, i.e. ErcoR1, cutting DNA at a particular site throughout its length so that dissimilar pieces of DNA with approximately the same length will overlap on the gel. DNA fragments larger than $c .20 \mathrm{~kb}$ will not separate during electrophoresis, so greatly reducing the range of DNA fragments which can be identified.
This problem can be overcome by using, sequentially, several different restriction enzymes. An alternative method is that of Jordens and Hall (1988) who digested DNA with the enzyme $B g l I I$.

The outbreak described, in which within 7 days the index case, seven other patients and three members of staff became infected, confirms the ease with which a strain of methicillin-resistant $S$. aureus can spread.

There has been some controversy over the virulence of non-epidemic methicillin-resistant isolates of $S$. aureus. Lacey and Chopra (1975) suggested that the genes required for multiple antibiotic resistance might limit the ability of a strain to spread. The non-epidemic outbreak strain described here spread quickly but paradoxically caused little sepsis: although five of the patients from whom it was recovered had neutropenia one only was infected (after Hickman line colonisation). In St Bartholomew's Hospital, strains of the typical EMRSA commonly cause infection leading to septicaemia, especially in patients with neutropenia. The new strain's failure to cause frequent infection suggests that it is of lower virulence, and justifies, with hindsight, the failure to close the ward during the outbreak.

These findings underline the need to distinguish between epidemic and non-epidemic methicillinresistant strains of $S$. aureus. To this end, immunoblot typing allows greater discrimination than DNA restriction pattern analysis and is highly reproducible.

We thank the doctors and staff on the oncology wards for their help with the identification and control of the outbreak, and the Division of Hospital Infection, Central Public Health Laboratory, Colindale, for the phage typing. JPB was supported by the Peel and Nuffield Trusts and RCM was a Wellcome Senior Research Fellow.

\section{REFERENCES}

Burnie J P, Matthews R C 1987 Immunoblot analysis: a new method for fingerprinting hospital pathogens. Journal of Immunological Methods 100: 41-46.

Burnie J P, Lee W 1988 A comparison of DNA and immunoblot fingerprinting of the $S$ II biotype of coagulase negative staphylococci. Epidemiology and Infection 101 : 203-212.

Feng-Ying C et al. 1986 Persistence of cholera in the United States: Isolation of Vibrio cholera O-1 from a patient with diarrhoea in Maryland. Journal of Clinical Microbiology 23: 624-626.

Gaston M A et al. 1988 Evaluation of electrophoretic methods for typing methicillin-resistant Staphylococcus aureus. Journal of Medical Microbiology 26: 189-197.

Jordens J Z, Hall L M C 1988 Characterisation of methicillin-

resistant Staphylococcus aureus isolates by restriction endonuclease digestion of chromosomal DNA. Journal of Medical Microbiology 27 : 117-123.

Krikler S J, Pennington T H Petrie D 1986 Typing of strains of Staphylococcus aureus by Western blot analysis of culture supernates. Journal of Medical Microbiology 21 : 169-171.

Lacey R W, Chopra I 1975 The effect of plasmid carriage on the virulence of Staphylococcus aureus. Journal of Medical Microbiology 8: 137-147.

Lacey R W, Barr K W, Barr V E, Inglis T J 1986 Properties of methicillin-resistant Staphylococcus aureus colonising patients in a burns unit. Journal of Hospital Infection 7: 137148.

Laemmli U K 1970 Cleavage of structural proteins during the assembly of the head of bacteriophage T4. Nature 227:680685 . 
Langenberg W, Rauws E A J, Widjojokusumo A, Tytgat G N J, Zanen H C 1986 Identification of Campylobacter pylori isolates by restriction endonuclease DNA analysis. Journal of Clinical Microbiology 24: 414-417.

Lee W, Burnie J P 1988 Fingerprinting methicillin-resistant Staphylococcus aureus by the immunoblot technique. Journal of Medical Microbiology 25 : 261-268.

Marples R R, Richardson J F, de Saxe M J 1986 Bacteriological characters of strains of Staphylococcus aureus submitted to a reference laboratory related to methicillin-resistance. Journal of Hygiene 96 : 217-223.

Parker M T 1972 Phage-typing of Staphylococcus aureus. In: Norris J R, Ribbons D W (eds) Methods in microbiology 7B, Academic Press, London, B1-28.

Report of Combined working party of the Hospital Infection
Society and British Society for Antimicrobial Chemotherapy 1986 Guidelines for the control of epidemic methicillin resistant Staphylococcus aureus. Journal of Hospital Infection 7: 193-201.

Scherer S. Stevens D A 1987 Application of DNA typing methods to epidemiology and taxonomy of Candida species. Journal of Clinical Microbiology 25 : 675-679.

Stephenson J R, Crook S J, Tabaqchali S 1986 New method for typing Staphylococcus aureus resistant to methicillin based on sulphur-35 methionine labelled proteins: its application in an outbreak. British Medical Journal 293: 581-583.

Stokes E J, Waterworth P M 1972 Antibiotic sensitivity tests by diffusion methods. Association of Clinical Pathologists, Broadsheet No. 55 . 